\title{
Biomimetic microenvironments for regenerative endodontics
}

\author{
Sagar N. Kaushik', Bogeun Kim', Alexander M. Cruz Walma', Sung Chul Choi ${ }^{3}$, Hui Wu², Jeremy J. Mao ${ }^{4}$, \\ Ho-Wook Jun ${ }^{1}$ and Kyounga Cheon ${ }^{2^{*}}$
}

\begin{abstract}
Regenerative endodontics has been proposed to replace damaged and underdeveloped tooth structures with normal pulp-dentin tissue by providing a natural extracellular matrix (ECM) mimicking environment; stem cells, signaling molecules, and scaffolds. In addition, clinical success of the regenerative endodontic treatments can be evidenced by absence of signs and symptoms; no bony pathology, a disinfected pulp, and the maturation of root dentin in length and thickness. In spite of the various approaches of regenerative endodontics, there are several major challenges that remain to be improved: a) the endodontic root canal is a strong harbor of the endodontic bacterial biofilm and the fundamental etiologic factors of recurrent endodontic diseases, (b) tooth discolorations are caused by antibiotics and filling materials, (c) cervical root fractures are caused by endodontic medicaments, (d) pulp tissue is not vascularized nor innervated, and (e) the dentin matrix is not developed with adequate root thickness and length. Generally, current clinical protocols and recent studies have shown a limited success of the pulp-dentin tissue regeneration. Throughout the various approaches, the construction of biomimetic microenvironments of pulp-dentin tissue is a key concept of the tissue engineering based regenerative endodontics. The biomimetic microenvironments are composed of a synthetic nano-scaled polymeric fiber structure that mimics native pulp ECM and functions as a scaffold of the pulp-dentin tissue complex. They will provide a framework of the pulp ECM, can deliver selective bioactive molecules, and may recruit pluripotent stem cells from the vicinity of the pulp apex. The polymeric nanofibers are produced by methods of self-assembly, electrospinning, and phase separation. In order to be applied to biomedical use, the polymeric nanofibers require biocompatibility, stability, and biodegradability. Therefore, this review focuses on the development and application of the biomimetic microenvironments of pulp-dentin tissue among the current regenerative endodontics.
\end{abstract}

Keywords: Regenerative endodontics, Pulp-dentin tissue, Revascularization, Extracellular matrix, Biomimetic microenvironments, Tissue engineering

\section{Background}

Regenerative endodontics has been proposed to replace damaged and underdeveloped tooth structures with normal pulp-dentin tissue based on the concept of tissue engineering [1-3] by providing natural extracellular matrix (ECM) mimicking environment; stem cells, signaling molecules, and scaffolds [4-7]. Clinical success of the regenerative endodontics can be evidenced by absence of signs and symptoms; no bony pathology, a disinfected pulp, and the maturation of root dentin in length and

\footnotetext{
* Correspondence: kcheon@uab.edu

${ }^{2}$ Department of Pediatric Dentistry, University of Alabama at Birmingham,

SDB 311, 1720 2nd Ave South, Birmingham, AL 35294-0007, USA

Full list of author information is available at the end of the article
}

thickness [6]. Current endodontic regeneration is often referred to as revascularization which disinfects the root canal using an antibiotic mixture and irritating the root apex tissue to form a blood clot inside the root canal to act as a natural scaffold and to support pulp-dentin stem cell proliferation and differentiation $[6,8,9]$. A blood clot can function as a scaffold for the ingrowth of new tissue since it consists of cross-linked fibrin $[9,10]$. This is the pathway for migration of cells and helps with the growth and differentiation factors [5]. Biodegradable scaffolds have been developed to deliver dental mesenchymal stem cells $[4,11]$. However, recent studies reported that the regenerated tissues from the revascularization are mainly dentin-like structure [12], cementum-like, and bone-like 
periodontal tissues [13-16]. Furthermore, the composition of the cells, signaling molecules, and scaffolds are not controllable to promote the pulp-dentin regeneration $[6,17]$. Yet, there are still concerns about stem cell resources, required amount, transplantation, and immune responses [18]. Recently, the concept of cell homing has been developed by the recruitment of endogenous mesenchymal stem cells around pulp apex tissue $[12,19,20]$. There are still several macromolecules under investigation to recruit the endogenous pulp cells efficiently using chemo-attractants, ECM molecules [21], or platelet-rich plasma [22].

Despite the variety of approaches of regenerative endodontics, there are several major challenges that remain: (a) The endodontic root canal is a strong harbor of the endodontic bacterial biofilm and the fundamental etiologic factors of recurrent endodontic diseases; therefore, effective disinfection is critical for the success of pulpdentin regeneration [6]; (b) Tooth discolorations were caused by minocycline (MC) [23] from the triple antibiotic mixture $[8,24]$ or mineral trioxide aggregates (MTA) [25]; (c) Cervical root fractures were reported due to the calcium hydroxide $\left(\mathrm{Ca}(\mathrm{OH})_{2}\right)$ [26-28]; (d) The scaffold should be biocompatible and biodegradable $[29,30]$; And (e) the pulp-dentin complex should be highly vascularized with innervated pulp as well as a dentin matrix with adequate root thickness and length $[4,6]$. Overall, the current clinical protocols have limited success in the regeneration of the pulp-dentin tissue.

Tissue engineering is the application of life sciences and biomaterials engineering for the development and advancement of tissue mimicking structures and the function of their natural counterparts [1, 31]. Existing cells, biomaterials, and the oral cavity's natural chemistry will be utilized to synthesize a natural-like microenvironment. Therefore, this review focuses on the development and application of the biomimetic microenvironments of pulpdentin tissue among the current regenerative endodontics.

\section{Review}

\section{Anatomy of pulp-dentin complex}

The dental pulp is comprised of loose connective tissues originated from the dental papilla of the tooth germ and their close proximity and interdependence cause the formation of the pulp-dentin complex separated by the outer layer of the dental papilla (odontoblast layer) [32]. Dentin and pulp tissue are confined with enamel tissue, which is not exposed on oral cavity; thus the proper understanding of the pulp-dentin complex is crucial for the development and progression of microenvironmentbased regeneration. Mature dentin is a mineralized form of the collagen-based predentin matrix and its crystalline structure primarily consists of hydroxyapatite and water that surrounds the dental pulp [33]. The pulp consists of pulp cells, odontoblasts, endothelial cells, neurons, immune system cells, and the ECM, which is crucial in maintaining the function of healthy teeth $[34,35]$. The apical foramen of the tooth allows for nutrients to be supplied and waste to be excreted through blood vessels [36]. Figure 1 demonstrates the characteristics of an immature tooth having an open apex, large canal, and a short root, which make the new tissue easily develop into the root canal space. Further the new tissue ultimately is regenerated into the coronal pulp chamber [37], which will promote revascularization and reinnervation [11]. On the other hand, a permanent tooth with a

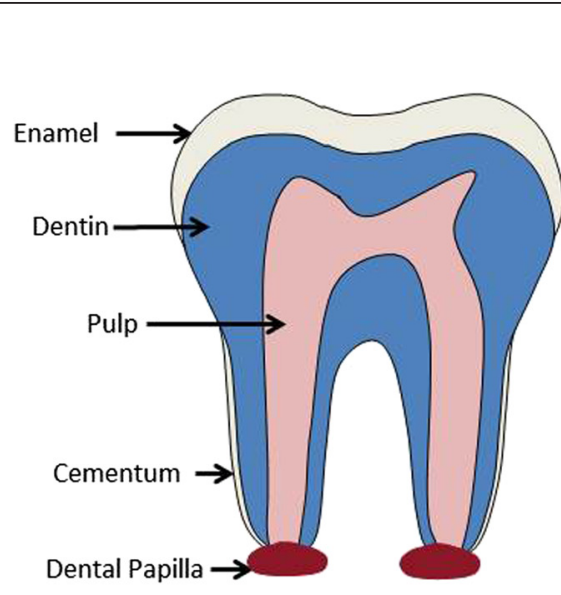

A

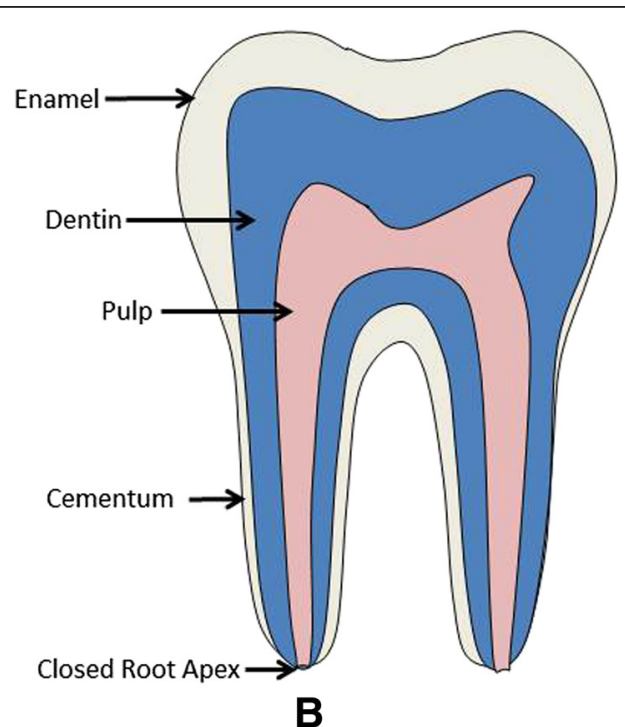

Fig. 1 Anatomy of tooth; (a) a healthy immature tooth with the distinct open root apex surrounded by dental papilla. $\mathbf{b}$ a healthy mature tooth with a closed root apex 
mature apex with a small canal may only have a limited amount of blood supply to allow ingrowth of tissue into the root canal space [38].

\section{Root end closure (Apexification)}

Steps for current revascularization for necrotic immature teeth involve opening the root canal and disinfecting with sodium hypochlorite $(\mathrm{NaOCl})$. Lower concentrations $(1.5 \%)$ of $\mathrm{NaOCl}$ and saline are used with an irrigating needle positioned about $1 \mathrm{~mm}$ from root end, to minimize cytotoxicity to stem cells in the apical tissues [39, 40]. Then, the area of the root canal is filled with a triple antibiotic paste, consisting of ciprofloxacin, metronidazole, and minocycline with inactive carriers (Macrogol ointment and Propylene glycol) [24, 37], for one to four weeks and sealed with temporary restorative material such as Cavit $^{\mathrm{Tm}}$, IRM ${ }^{\mathrm{Tm}}$, glass-ionomer or another temporary material [39]. At the consequent follow up, the treated root canal is accessed to remove the antibiotic paste upon the re-evaluation of the signs and symptoms, irrigated with $17 \%$ Ethylenediaminetetraacetic acid (EDTA) to release growth factors from the dentin [41], and the root apex is stimulated to form a blood clot into canal by overinstrumenting endodontic files and bleeding is confined at the level of cemento-enamel junction avoiding tooth discoloration. A resorbable matrix (CollaPlug ${ }^{\mathrm{mix}}$, Collacote ${ }^{\mathrm{max}}$, or CollaTape ${ }^{\mathrm{Tm}}$ ) is placed on top of the blood clot, then sealed with a MTA with/without $\mathrm{Ca}(\mathrm{OH})_{2}$ as a capping material [39, 42-45]. Several challenges were reported from the apexification procedure of immature necrotic teeth [42].

\section{Challenges for apexification procedures Discoloration of tooth}

One of the main problems from the use of the current protocol is the discoloration of the tooth crown due to the use of tetracycline (e.g. minocycline) in the triple antibiotic mixture [24, 46, 47]. Therefore, minocycline was replaced with other equivalent antibiotics in recent studies (e.g. cephalosporin, amoxicillin etc.,) resulting in no further discoloration [42, 48, 49]. Other studies showed that the combination of metronidazole and ciprofloxacin with any of these antibiotics was just as effective in sterilizing carious and endodontic lesions [49]. Another solution to avoid the tooth discoloration can be observed in a modified protocol by sealing the dentinal tubules using MTA below the gingival margin [23, 47]. Along with the sealing dentinal tubules, intra-coronal bleaching with sodium perborate using white MTA instead of grey MTA is also suggested [23].

\section{Cervical root fracture}

Traditionally, $\mathrm{Ca}(\mathrm{OH})_{2}$ was used for the apexification procedure of the immature root with pulpal necrosis as the intra-canal medicament [50]. In spite of the reported clinical success, there are potential complications for the traditional protocol $[27,51]$. Due to its high $\mathrm{pH}$, calcium hydroxide can cause necrosis of tissues that could potentially differentiate into new pulp. Apexification procedures can leave the immature tooth fragile because the root remains short with thin, radicular walls, making the tooth more susceptible to fracture [51]. In cases disinfected by calcium hydroxide, root canal calcification/obliteration was observed [52-54]. Studies conducted by Andreasen and other researchers have demonstrated that the traditional use of long-term application of $\mathrm{Ca}(\mathrm{OH})_{2}$ can lead to a weaker tooth more susceptible to fracture $[27,55,56]$. In addition, $\mathrm{Ca}(\mathrm{OH})_{2}$ procedure requires a long treatment period for the formation of the calcified barrier from 3 to 24 months with multiple applications [50, 57].

\section{Creation of blood clot}

In the current protocol, blood clot is created by overinstrumenting beyond the root apex to provide scaffold inducing source of growth factors and repairing pulp tissue $[9,42,58,59]$. The induced blood clot may serve as a natural scaffold to allow the migration of stem cells along the canal $[8,38]$. However, the inability to consistently produce an ideal blood clot was also observed [42] and limited tissue regeneration was observed. Absence of a blood clot would hinder such a migration, which may be caused by the vasoconstrictor epinephrine in the local anesthetic solution [38, 42]. To resolve the issues, local anesthetic without a vasoconstrictor can be chosen [42]. Meanwhile, there are concerns for the stimulated pulp bleeding which may not be the ideal procedure or function as a scaffold to induce the pluripotent stem cells resulting uncertain pulp-dentin tissue regeneration $[4,20]$.

\section{Poor root development}

Ideal root development pattern in immature teeth would include an increase in root length and wall thickness with formation of the root apex [15]. However, tooth necrosis followed by regenerative endodontic treatments has been reported to have an absence of increase in root length and root wall thickness, or a lack of tooth apex formation $[54,60,61]$.

A retrospective evaluation of radiographic outcomes discovered that regenerative endodontic treatment with triple antibiotic dressing increased root length more than MTA apexification and root wall thickness significantly more than either $\mathrm{Ca}(\mathrm{OH})_{2}$ or formocresol [62]. Yet, the replaced structures were found to be periodontal tooth structures such as cementum-like, bone-like, or fibrous connective tissue structures by histologic sections [13-15, 63]. Yamauchi et al. attempted to improve 
dentin formation through the use of a cross-linked collagen scaffold in the canal spaces of dogs with apical periodontitis. The results showed the formation of distinct mineralized tissues, dentin-associated mineralized tissue (DAMT) and bony islands (BIs) [64]. Through immunohistochemical analysis, it was determined that DAMT resembled cementum without any vasculature. The BIs were found to resemble bone because it was vascularized with lacunae and "bone marrow-like" structures [65]. However, there was no evidence of pulp-like tissue or dentin-like structures in any of specimens, which are the key components in endodontic tissue regeneration. Yamauchi et al. recommend the incorporation of "some factors into the scaffold that facilitate the differentiation of stem cells to odontoblasts" in order to create the pulp-dentin complex [64].

\section{Cytotoxicity}

Intracanal medicament, antibiotics can induce cytotoxic effect on dental pulp stem cells [49]; it can be due to the lowered $\mathrm{pH}$ from the antibiotics, minocycline hydrochloride and ciprofloxacin hydrochloride $(\mathrm{HCl})$, which are used in the triple antibiotic mixture. The release of hydrogen ions from $\mathrm{HCl}$ groups resulted in an acidic condition, which can be an unfavorable condition for culturing cells [66]. Conversely, recent in vitro cytotoxicity studies demonstrated that metronidazole did not inversely affect human dental pulp cells (DPCs) and apical papilla cells (APCs) even at the $25.00 \mathrm{mg} / \mathrm{mL}$ concentration. Metronidazole solution may have a neutral $\mathrm{pH}$, which can explain why cytotoxicity did not occur [67]. On the other hand, the triple antibiotic at $0.39 \mathrm{mg} /$ $\mathrm{mL}$ had a less cytotoxic effect on DPCs and APCs viability [67]. The single antibiotic with the concentrations of $0.024 \mu \mathrm{g} / \mathrm{mL}$ maintained dental pulp cell viability for 7 days [67]. Also, lower than $2.5 \mathrm{mg} / \mathrm{mL}$ of the triple antibiotic and $\mathrm{Ca}(\mathrm{OH})_{2}$ demonstrated no cytotoxicity on the DPCs using lactate dehydrogenase activity assay [68]. Therefore, the concentration of triple antibiotic in clinical usage suggested to be adjusted not to cause cytotoxicity on the remaining vital tissues.

\section{Development of regenerative endodontic procedures (REP)}

Tooth development is the multistage process between oral epithelium and mesenchymal origin, resulting in the formation of the dentin matrix and pulp-dentin complex. Ectomesenchymal stem cells from dental papilla differentiate into dentin-forming odontoblasts [69, 70]. Hertwig's epithelial root sheath (HERS) from the inner and outer enamel epithelium are critical components in the process since they guide the underlying mesenchymal cells from the dental papilla and follicle to differentiate into odontoblast, pulp fibroblast, and cementoblast of the root [14]. Through this development, root dentin would increase in length and thickness.

In a study conducted by Murray et al., the researchers used the term "regenerative endodontic procedures" (REPs), which is a 'biologically based procedure designed to replace damaged structures' such as root dentin along with cells of the pulp-dentin complex [2]. The goal in REP is to provide a suitable environment in the root canal that will promote repopulation of the osteo/odonto progenitor stem cells, regeneration of pulp tissue, and continued root development [36]. Endodontic treatment utilizing osteo/odonto progenitor stem cells in the apical papilla is resistant to the infection and necrosis caused by proximity to periodontal blood supply [38].

REP has been shown to have distinct differentiation potential using mesenchymal stem cells markers $[39,71]$. In a study conducted by Hristov et al., blood vessels were identified through the use of double-immunostaining for CD31/ collagen-IV and Vascular endothelial growth factor (VEGF)R2/Collagen-IV; the process of revascularization was occurring in the endothelial progenitor cells during their differentiation [72]. Despite the lack of REP-associated clinical trials, clinicians continue to use this method for treatment. The American Association of Endodontics (AAE) commented on this controversy and said that regenerative endodontics is 'one of the most exciting new developments in dentistry today.' After this, the AAE developed treatment considerations and asked practitioners to use this approach while keeping the new research findings in mind $[39,73]$. Therefore, the REP may provide a sufficient disinfection and influence cell survival, migration, angiogenesis, proliferation, and differentiation [62].

\section{Revascularization or Revitalization}

The formation of blood vessels around the teeth that provide blood supply in teeth is known as vascularization, which is important in tooth development and function [8]. Therefore, the term "revascularization" was coined from a case report describing the re-establishment of blood supply in teeth with incomplete root formation after an autotransplantation or replantation. In a study conducted by Iwaya et al., revascularization was suggested to treat an immature permanent tooth with 'apical periodontics and sinus tract', as an alternative procedure to apexification $[26,74]$. As demonstrated by Kling et al., successful regeneration is dependent on the rates of formation of new tissues versus the bacterial growth. If the radiographic opening is more than $1.1 \mathrm{~mm}$, the incidence of revascularization is enhanced. As a part of the revascularization treatment, a blood clot is created after the canal is disinfected to act as a matrix for the growth of new tissue in the space [75]. Banchs and Trope used a double seal with MTA and bonded resin to prevent any bacteria from invading the pulp space before the revascularization could 
occur [8]. Along the same lines, "revitalization" is a term that describes an endodontic procedure used to rejuvenate tooth vitality in the case of necrotic stages; "regeneration" in endodontics has been defined as procedures of replacing lost or damaged pulp-dentin tissues complex [2]. However, histological studies show that the tissue found in root canals may not be through the exact regeneration process, but instead through healing process which is known as "repair". The repair of the tissue has been used when the healed tissue inside the root canal recovers the similar form and elements of pulp tissue [76].

\section{Bioengineering approaches for REP Dental stem cells}

The fields of stem-cell based pulp-dentin regeneration along with cell-free approaches have been developed. Recently, a new population of mesenchymal stem cells (MSCs) has been discovered stem cells from the apical papilla (SCAP) of immature teeth and stem cells from human exfoliated deciduous teeth (SHED) derived from pulp tissue or the precursor of pulp [77-79]. They have been shown to be distinct from dental pulp stem cells (DPSCs) through histologic, immunohistochemical, cellular, and molecular analyses [80], and seem to be responsible for dentin formation in the root [38]. Autologous DPSCs with growth factor, bone morphogenetic proteins (BMP) 2 has successfully shown partial pulp regeneration in a dog model [81]. Furthermore, DPSCs was shown to produce neurotrophic factors to induce neural tissue development [77, 82]. Besides SCAP, which has shown promising pulp regeneration capability, subpopulations of pulp stem cells, bone marrow MSCs (BMMSCs) and adipose tissue-derived MSCs (ADMSCs) also can regenerate pulp tissue [83]. A growing amount of evidence is demonstrating that SCAP is the source of the primary odontoblasts for the formation of the root dentin, whereas DPSCs are the source of replacement odontoblasts. Critical roles of the SCAP for the continued root formation are highlighted [38] and the SCAP and other type of stem cells (e.g. periodontal ligament stem cells) can be combined for the root regeneration [78]. In order to evaluate the regenerative potential, DPSCs and SCAP were encapsulated into a scaffold and inserted into section of human tooth root canal and transplanted into severe combined immunodeficiency mice subcutaneously for three to four months; as a result, pulp space was filled with vascularized pulp-like tissue and uniform dentin-like layer at dentin wall and MTA cement [11]. Therefore, a stem cell based engineering approach can provide realistic pulp-dentin regeneration. In addition, vascularization is a critical component of pulp-dentin regeneration, which can be accelerated with several angiogenic factors; VEGF and platelet-derived growth factor [84-86].

\section{Nitric oxide}

Angiogenesis is an important process that is required for many pathological and wound healing processes. VEGF is an inducer of angiogenesis that promotes the vessel formation. Nitric oxide (NO) is a lipophilic molecule that can easily permeate biological membrane barriers and has been found to be a potent vasodilator [87] and the amount of $\mathrm{NO}$ can also regulate VEGF [88]. In addition, NO releasing dendrimers are reported as effective antibacterial agents $[89,90]$. They tested a series of NO-releasing poly (propylene imine) (PPI) dendrimers and control PPI dendrimers (non-NO-releasing) against Gram-positive and Gram-negative pathogenic bacteria. It was found that the NO-releasing PPI dendrimers killed $>99.99 \%$ of all bacterial strain tested with a minimal toxicity to mammalian fibroblasts [89]. Through this dual function of NO, NO releasing scaffolds can be utilized in REP and other tissue engineering fields.

\section{Bone morphogenetic proteins}

Bone morphogenetic proteins (BMPs) have been implicated in tooth development, and the expression of BMP2 is increased during the terminal differentiation of odontoblasts [91, 92]. Beads soaked in human recombinant BMP2 induce the mRNA expression of dentin sialophosphoprotein (DSPP), the differentiation marker of odontoblasts and indication of producing of dentin matrix proteins after implantation onto dental papilla in organ culture. BMP2 also induces a large amount of reparative dentin on the amputated pulp in vivo [93]. BMP2 may play a role in regulating the differentiation of pulp cells into odontoblastic lineage and also stimulate reparative dentin formation [92].

\section{Enamel-like fluorapatite surfaces}

Previous studies have also demonstrated good biocompatibility of both the ordered (OR) and disordered (DS) Fluorapatite (FA) crystal surfaces in providing a favorable environment for functional cell-matrix interactions of human DPSCs [94, 95]. In addition, studies have shown long-term growth of human DPSCs. Specifically, enhanced cellular response of DPSCs to the OR FA crystal surface has been observed $[95,96]$. This can be further manipulated by treating with dentin-inducingsupplement to produce a dentin/enamel superstructure $[94,95]$. Studies have shown that FA crystal surfaces, especially the OR FA surface, indeed can and did mimic the physical structure of enamel and also provided a favorable extracellular microenvironment for the cells $[95,96]$. Furthermore, FA crystal surfaces induced and stimulated differentiation of human DPSCs and mineralization of tissue formation without a mineralization supplement. Such findings display the promising benefits of utilizing FA crystal surfaces as a simple biomimetic model for dentin 
regeneration, enamel/dentin/pulp complex creation, and also as a scaffold for hard tissue engineering [96].

\section{Platelet-rich plasma}

Platelet-rich plasma (PRP) contains multiple growth factors, which include platelet-derived growth factor, transforming growth factor $b$, and insulin-like growth factor [97]. Thus, PRP may be a good supplement for cellbased pulp/dentin regeneration. PRP, which can be derived from a patient's own blood, is easy to prepare and can also form a three-dimensional fibrin matrix that can act as a scaffold [36, 98, 99]. An in vitro study showed that PRP can enhance the proliferation and differentiation of human DPSCs [100]. In the present study, only PRP or the combination of PRP and DPSCs did not enhance the true regeneration of necrotic tissue rather stimulate tissue repair with newly formed cementum like, bone like, and connective tissues [101]. Another collagen scaffold used by Iohara et al. to carry DPSCs into the canals may provide a better condition for pulp regeneration compared [102]. The in vitro study showed that, although PRP can enhance mineralization differentiation of DPSCs, it is not clear whether PRP enhances dentinogenesis (i.e., PRP may not promote pulp-dentin regeneration) [100].

\section{Cell homing}

Some researchers have also seen positive results of the regeneration of pulp-like tissue through chemotaxis induced cell homing $[12,19,20]$. The cell homing is a process, migration of mobilized hematopoietic stem cells via vascular structure toward certain tissues (e.g. any organs, injured tissues) using active navigation [103-105]. This concept leaves potential pulp-dentin re-cellularization and revascularization with or without active apical papilla tissue. A variation of pulp-dentin regeneration can be resulted from the combination of cell homing with cell transplantation and a variety of the growth factors [76]. Therefore, the migrated SCAP in periapical tissues is reported to have a positive role to be differentiated into pulp-dentin forming cells $[38,78]$. However, the migrated MSCs in periapical tissues may form ectopic periodontal tissue in the pulp space $[13,14]$. Besides, BMSCs are also considered for migrated source of forming pulp tissue [106]. During the homing process, various growth factors play a critical role to assist stem cells; for example, BMP7 was delivered to promote the regeneration of dentin-like tissue and create an ideal microenvironment [12]. Stem/progenitor cellbased approaches are also being studied by researchers. Stem/progenitor cells from apical papilla and DPSCs were isolated and seeded onto a synthetic porous scaffolds consisting of poly-D, L-lactide and glycolide [107]. Subsequently, dentin-like tissue was observed expressing by dentin sialophosphoprotein, bone sialoprotein, alkaline phosphatase, and CD105 as would their natural counterparts [107].

\section{Biomimetic microenvironments}

To regenerate the function and form of the pulpdentin complex, the construction of the biomimetic microenvironment is a key factor. Cells respond differently to physicochemical and mechanical properties of the microenvironment. The interactions between cells and the ECM control differentiation, migration, and proliferation, as well as tissue remodeling. For this reason, an ECM mimicking microenvironment has been designed by incorporating various moieties and features derived from the ECM. Biomimetic environments, such as ECM microenvironments through peptide amphiphiles (PA), cell homing, stems cells and through growth factors, have been developed [1, 8, 26, 107].

ECM proteins potentially carry problems for clinical applications including undesirable immune responses, higher risks for infection, variety in biological sources, and increased clinical costs [108]. To overcome such limitations, small peptide sequences derived from ECM proteins have been utilized such as Gly-Arg-Gly-Asp-Ser (GRGS) [109, 110]. However, these isolated ECM peptides still possess some limitations of encapsulating biomaterials. For example, after implantation, entrapping cells in photo-polymerized biomaterials can potentially have many problems, such as the formation of fibrotic processes, poor degradation of the scaffold, and local and/or systemic toxicity [111]. Studies have also shown that different compositions and concentrations of alginate can affect the cellular overgrowth of implanted capsules. This can be due to the formation of the metabolic barriers to nutrient diffusion around the implant if inadequate levels of the material are used [112]. To overcome such limitations, nano-scale PA nanomatrix gels [113] have been proposed as a promising solution by synthetically recapitulating the ECM structure as shown in Figs. 2 and 3. PA nanomatrix gel possesses such qualities: rapid gel-like 3D network formation by selfassembly, versatility to incorporate various cell adhesive moieties, and cell-mediated degradable sites (matrix metalloproteinase-2) for progressive scaffold degradation and eventual replacement by host-ECM [114].

The PA is a hydrophilic head, consisting of a functional peptide sequence, attached to a hydrophobic alkyl tail. The internal peptide structure can be modified to mimic the characteristic properties of the natural ECM [115-118]. Furthermore, PA self-assembles into long cylindrical structures which are $8-10 \mathrm{~nm}$ in diameter and up to several microns in length. As seen in Fig. 4, Kaushik et al. have developed a biomimetic antibiotic releasing nanomatrix gel that demonstrates synergistic antibacterial effects, which may be effective for root canal 


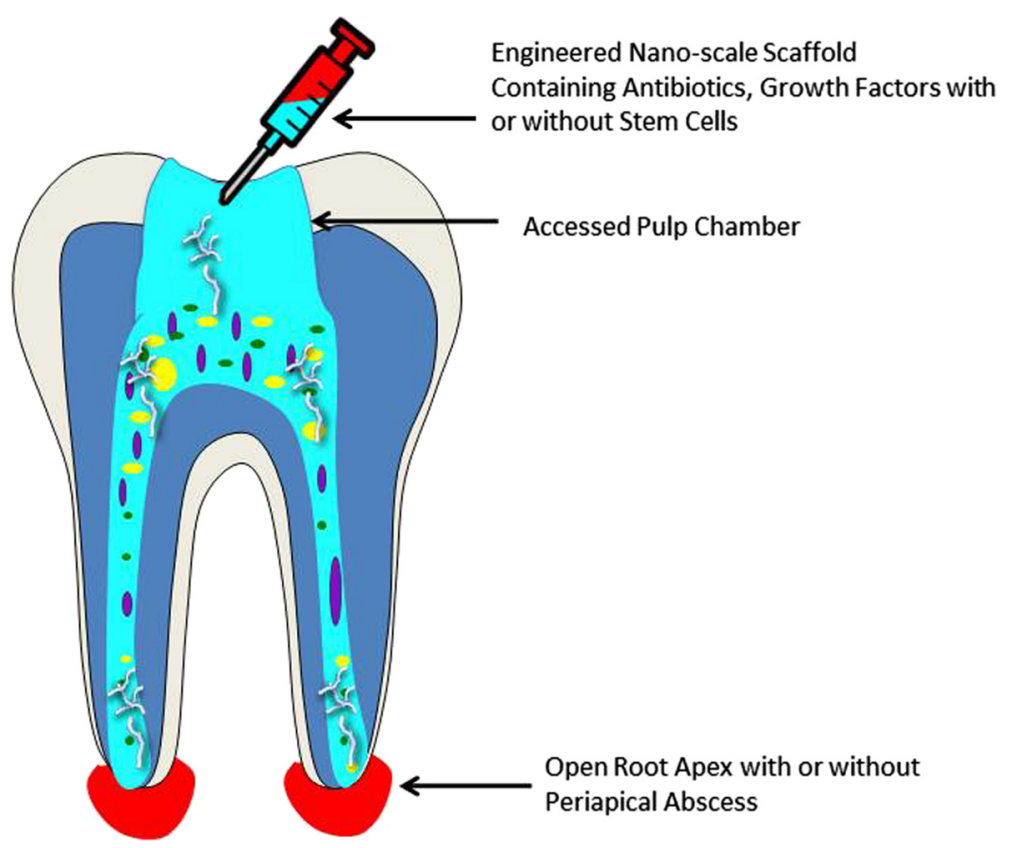

Fig. 2 Engineered nano-scale scaffold for the regenerative endodontics treatment for an infected tooth; after removal of infected pulp-dentin tissue; the root canal is irrigated with $\mathrm{NaOCl}$ and EDTA. Engineered nano-scale scaffold containing a mixture of antibiotics, growth factors, and/or stem cells is applied to the root canal

disinfections and eliminates the use of minocycline, which is used in the traditional protocol [119]. The development of the gel, which uses PA for the encapsulation of the antibiotics to create a sustained local release drug delivery system, is still in preliminary stages but shows very promising results in early studies. The developed gel, which contains ciprofloxacin and metronidazole, was tested against two prominent bacterial strains in endodontic infections, E. faecalis and T. denticola. Their results portrayed that the developed gel had a greater synergistic antibacterial effect than the antibiotics alone [119].

\section{Animal models for microenvironment viability}

Recently, there are DPSCs that have been used in both small and large animals, which demonstrate that pulp or dentin like tissues are able to regenerate either partially or completely for the root canal space [84]. An experimental animal model is required with comparable "anatomical, physiologic, histologic, and pathologic characteristics to the ultimate treatment cohort [120]." This means that the animal model should have relatively large teeth that are easily accessible and able to be radiographed. It is also preferred

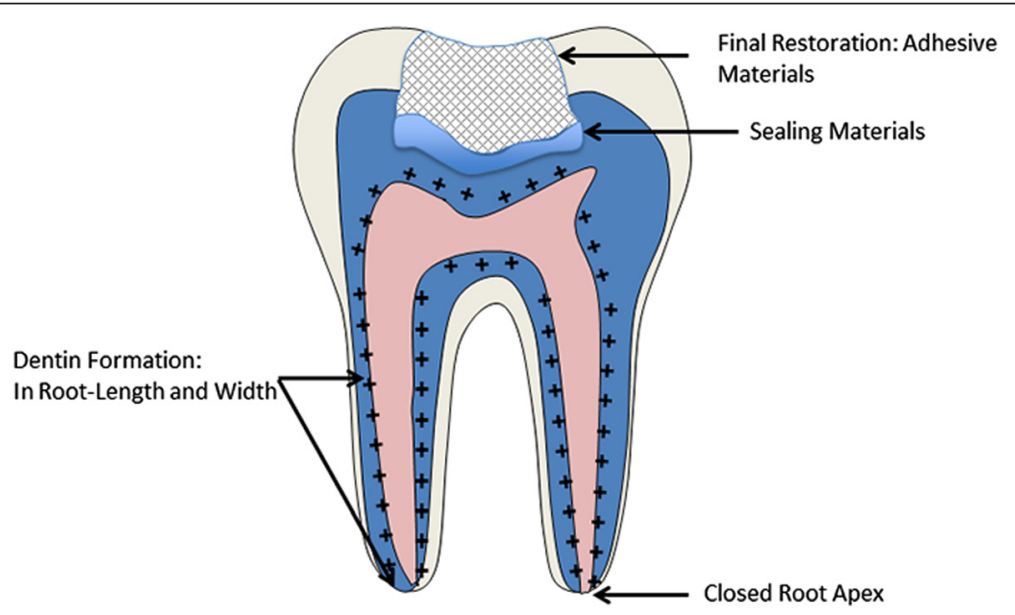

Fig. 3 Regenerated pulp-dentin tissue with closed root apex; regenerated pulp-dentin tissue with closed root apex is observed after the regenerative endodontic treatment using an engineered nano-scale scaffold. Removed coronal structure is restored with adhesive materials with base sealing materials. Plus $(+)$ signs indicate the area of dentin formation 
(A)

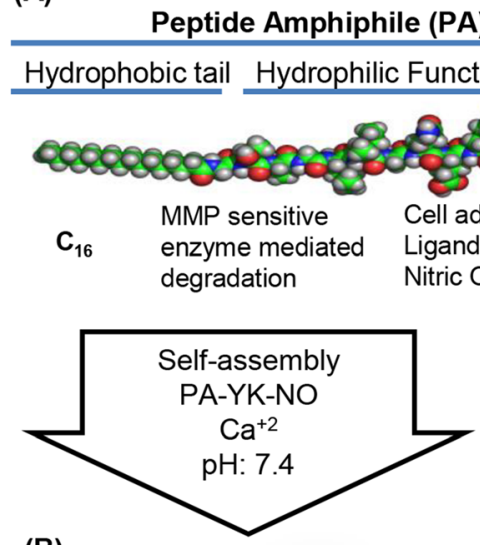

(B)

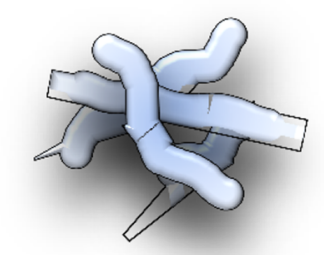

(D)
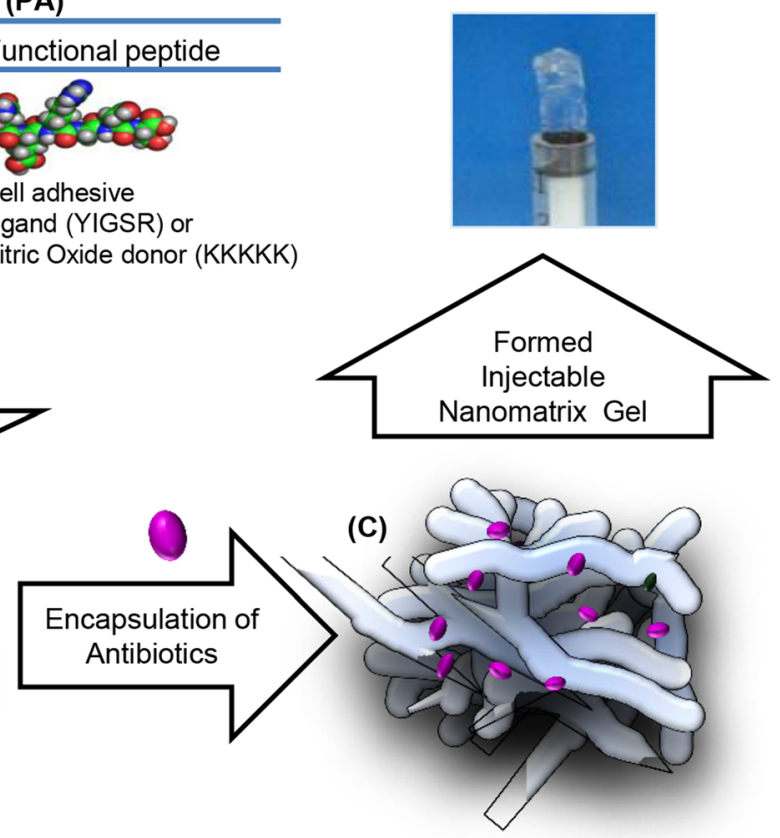

Fig. 4 General scheme of the design for the biomimetic approach; (a). Synthesis of peptide amphiphiles (PAs), (b). Self-assembly of PAs, (c). Encapsulation of antibiotics, (d). Formation of the nanomatrix gel, Modified with permission from Kaushik et al. [119]

that the model be inexpensive and readily available. The advantages and disadvantages of various animal models, including rats, cats, ferrets, dogs, and primates are discussed.

\section{Rats}

Rats and mice are the preferred animal model in many fields of research because they are inexpensive, convenient, and well understood. They are convenient because they are small and easily maintained, and can be bought in relatively large quantities for low prices. Unfortunately, rodents' teeth are too small for experiments in regenerative endodontics, though they have been used successfully in studies regarding pulp and periapical tissue reactions [121]. Similarly, guinea pigs and rabbits have teeth that are simply too small for endodontic regenerative studies. A study conducted by Zhao et al. used transplanted rat teeth, and demonstrated that in some cases there was revascularization of the pulp, and dentin-like structures were able to form on the root wall [122]. This auto-transplantation study may provide insight into the biological process of the regeneration of the pulp-dentin complex.

\section{Ferrets}

Numerous areas of research have utilized the ferret including neuroscience, pathogenesis, endocrinology, and the study of numerous diseases. However, the ferret has not been used extensively in the field of endodontics.
Due to the accessibility and larger size of the ferret's single-rooted cuspid, the ferret is more suitable for endodontic regenerative studies than rodents and rabbits. Additionally, the ferret is subject to less ethical objections than dogs, cats, and primates as well as being more readily available and less expensive [123]. A study in 2011, conducted by Torabinejad et al., investigated into the use of ferret cuspid as a model for regenerative endodontics using radiography [120]. It was determined that a ferret's cuspid teeth erupted around 50 days after birth with open apices. At 52 days, the HERS "was extending to form the root, with very thin walls, a wide canal space, and an open apex" [120]. Apical closure began at approximately 90 days, continuing until complete closure observed at 133 days. The study concluded the most appropriate time to conduct studies on ferret teeth is during the 50-90 days when the open apex allows communication between the root canal system and the periapical tissue. Torabinejad et al. stress that more research into the ferret model is required, with the need for the development of a stem cell population in the ferret pulp and periapical tissues, in addition to the development of specific antibodies that can decisively identify relevant dental tissues [120].

\section{Cats}

Cats can provide four large single-rooted cuspids that are similar in craniofacial characteristics to humans. 
Wilson found that all permanent teeth before the age of six months are erupted and have open apices, with closure of cuspids occurring approximately at nine months, and complete closure at eleven months [124]. Cats are relatively expensive to purchase and maintain. Additionally, there has been an increase in public objection to the use of cats in research because they are common domesticated pets in numerous cultures.

\section{Dogs}

Dogs have been used in various endodontic researches, including regenerative studies [13, 64, 125, 126]. Apices of permanent teeth remain open until 6 months of age and will be closed at 10 months old [127]. Khademi et al. used single-rooted premolars and maxillary incisors from 3 immature mongrel dog's to induce periapical lesions for the evaluation of the success rate of a revascularization treatment protocol [125]. Mandibular incisors were deemed unsuitable due to their susceptibility to fracture under large masticatory forces, and the apex closes before sufficient dentinal wall can develop. In addition, the proximity of mandibular roots makes it difficult to take clear radiographic images. Induced necrotic-infected teeth can develop periapical lesions after about 28 days. In the dog model, the "dental pulp tissue possesses a capacity for spontaneous repair by the formation of reparative dentin, but only up to a defect size of $2 \mathrm{~mm}$ in diameter and $1 \mathrm{~mm}$ in depth [126]."

\section{Primates}

Primates, being the closest ancestor to humans, are the ideal animal models for a lot of medical and dental research [121]. Although longitudinal studies on the age of eruption and root end closure in different species of primates are unavailable, Anemone et al. studied apical closure radiographically in chimpanzees. Although primates are the most similar to humans, they are not used extensively due to their high cost to purchase and maintain in addition to the difficulty of handling. There are also the ethical problems that come with the fact that primates are so similar to humans.

\section{Conclusions}

This review article is focused on the current prospects on biomimetic microenvironments as a scaffold of pulpdentin complex regeneration via current tissue engineering concepts. The proper biomimetic microenvironments can be constructed upon the synthetic nano-scaled peptide amphiphiles through bioengineered regeneration process in combination with various bioactive molecules, growth factors, and stem cells to mimic native pulp ECM. From the animal models, currently the dog model is favorable to perform regenerative endodontic studies due to its availability and similarity of the size and number of teeth for the creation of a biomimetic microenvironment. In spite of the promising data from in vitro and some animal experiments, the future advances in pulp-dentin tissue regeneration are required to show the functional tissue regeneration in addition to the favorable clinical outcomes.

\begin{abstract}
Abbreviations
AAE, American Association of Endodontists; ADMSCs, adipose tissue-derived MSCs; APCs, apical papilla cells; Bls, bony islands; BMMSCs, bone marrow MSCs; BMPs, bone morphogenetic proteins; $\mathrm{Ca}(\mathrm{OH})_{2}$, calcium hydroxide; DAMT, dentin-associated mineralized tissue; DPCs, dental pulp cells; DPSCs, dental pulp stem cells; DSPP, dentin sialophosphoprotein; ECM, extracellular matrix; EDTA, ethylenediaminetetraacetic acid; FA, fluorapatite; $\mathrm{HCl}$, hydrochloride; HERS, Hertwig's epithelial root sheath; MC, minocycline; MSCs, mesenchymal stem cells; MTA, mineral trioxide aggregates; $\mathrm{NaOCl}$, sodium hypochlorite; NO, nitric oxide; PAs, peptide amphiphiles; PPI, propylene imine; PRP, platelet-rich plasma; REP, regenerative endodontic procedures; SCAP, stem cells from the apical papilla; SHED, stem cells from human exfoliated deciduous teeth; VEGF, vascular endothelial growth factor.
\end{abstract}

\section{Funding}

This study was supported by NIH Loan Repayment Program (KC), UAB SOE Undergraduate Research Award (SNK), NSF CAREER (CBET-0,952,974, HWJ), $\mathrm{NIH}$ (1R01HL125391, HWJ).

Availability of data and materials

Not applicable.

\section{Authors' contributions}

All authors read and approved the final manuscript. SNK was responsible for the writing of the overall review, the anatomy and regenerative endodontics sections. BK was responsible for the writing of overall review and the problems of regeneration. ACW was responsible for the writing of overall review, animal models, and Figures. HW was responsible for the overall review. JJM was responsible for the overall review. HWJ was responsible for writing the recent bioengineering approaches section. KC was responsible for selecting topics, directing the overall paper organization, and editing of review.

\section{Authors' information}

SCC: Professor and Chair, Department of Pediatric Dentistry at Kyung Hee University, 1Hoegi-dong, Dongdaemoon-Gu, 130-702, Seoul, Korea HW: Professor, Department of Pediatric Dentistry at University of Alabama at Birmingham, SDB 802, $19197^{\text {th }}$ Avenue South, Birmingham, AL 35,294, USA JJM: Professor and Co-director, Center for Craniofacial Regeneration at Columbia University, 630 W. 168 Street, VC12-211, New York, NY 10,032, USA HWJ: Associate Professor, Department of Biomedical Engineering, University of Alabama at Birmingham, Shelby Building 806, 1825 University Boulevard, Birmingham, AL 35,294, USA

KC: Instructor, Department of Pediatric Dentistry at University of Alabama at Birmingham, SDB 311

$19197^{\text {th }}$ Avenue South, Birmingham, AL 35,294, USA.

\section{Competing interests}

The authors declare that they have no competing interests.

\section{Consent for publication}

Not applicable.

Ethics approval and consent to participate

Not applicable.

\section{Author details}

${ }^{1}$ Department of Biomedical Engineering, University of Alabama at Birmingham, Birmingham, USA. ²Department of Pediatric Dentistry, University of Alabama at Birmingham, SDB 311, 1720 2nd Ave South, Birmingham, AL 35294-0007, USA. Department of Pediatric Dentistry, Kyung Hee University, Seoul, South Korea. ${ }^{4}$ Center for Craniofacial Regeneration at Columbia University, New York City, NY, USA. 


\section{Received: 11 April 2016 Accepted: 24 May 2016}

Published online: 02 June 2016

\section{References}

1. Langer R, Vacanti JP. Tissue engineering. Science. 1993;260:920-6.

2. Murray PE, Garcia-Godoy F, Hargreaves KM. Regenerative endodontics: a review of current status and a call for action. J Endod. 2007:33:377-90.

3. Mooney DJ, Powell C, Piana J, Rutherford B. Engineering dental pulp-like tissue in vitro. Biotechnol Prog. 1996;12:865-8.

4. Albuquerque MT, Valera MC, Nakashima M, Nor JE, Bottino MC. Tissueengineering-based strategies for regenerative endodontics. J Dent Res. 2014;93:1222-31.

5. Huang GT. Pulp and dentin tissue engineering and regeneration: current progress. Regen Med. 2009;4:697-707.

6. Hargreaves KM, Diogenes A, Teixeira FB. Treatment options: biological basis of regenerative endodontic procedures. J Endod. 2013;39:S30-43.

7. Yuan Z, Nie H, Wang S, Lee CH, Li A, Fu SY, Zhou H, Chen L, Mao J J J Biomaterial selection for tooth regeneration. Tissue Eng Part B Rev. 2011;17: 373-88.

8. Banchs F, Trope M. Revascularization of immature permanent teeth with apical periodontitis: new treatment protocol? J Endod. 2004;30:196-200.

9. Ostby BN. The role of the blood clot in endodontic therapy. An experimental histologic study. Acta Odontol Scand. 1961;19:324-53.

10. Skoglund A, Tronstad L, Wallenius K. A microangiographic study of vascular changes in replanted and autotransplanted teeth of young dogs. Oral Surg Oral Med Oral Pathol. 1978:45:17-28.

11. Huang GT. Dental pulp and dentin tissue engineering and regeneration: advancement and challenge. Front Biosci (Elite Ed). 2011:3:788-800.

12. Kim JY, Xin X, Moioli EK, Chung J, Lee CH, Chen M, Fu SY, Koch PD, Mao J. Regeneration of dental-pulp-like tissue by chemotaxis-induced cell homing. Tissue Eng Part A. 2010;16:3023-31.

13. Wang X, Thibodeau B, Trope M, Lin LM, Huang GT. Histologic characterization of regenerated tissues in canal space after the revitalization/revascularization procedure of immature dog teeth with apical periodontitis. J Endod. 2010;36:56-63.

14. Shimizu E, Jong G, Partridge N, Rosenberg PA, Lin LM. Histologic observation of a human immature permanent tooth with irreversible pulpitis after revascularization/regeneration procedure. J Endod. 2012;38:1293-7.

15. Nosrat A, Homayounfar N, Oloomi K. Drawbacks and unfavorable outcomes of regenerative endodontic treatments of necrotic immature teeth: a literature review and report of a case. J Endod. 2012;38:1428-34.

16. About I, Bottero MJ, de Denato P, Camps J, Franquin JC, Mitsiadis TA. Human dentin production in vitro. Exp Cell Res. 2000;258:33-41.

17. Friedlander LT, Cullinan MP, Love RM. Dental stem cells and their potential role in apexogenesis and apexification. Int Endod J. 2009;42:955-62.

18. Schmalz G, Smith AJ. Pulp development, repair, and regeneration: challenges of the transition from traditional dentistry to biologically based therapies. J Endod. 2014:40:\$2-5.

19. Kim SG, Zheng Y, Zhou J, Chen M, Embree MC, Song K, Jiang N, Mao JJ. Dentin and dental pulp regeneration by the patient's endogenous cells. Endod Topics. 2013;28:106-17.

20. Mao JJ, Kim SG, Zhou J, Ye L, Cho S, Suzuki T, Fu SY, Yang R, Zhou X. Regenerative endodontics: barriers and strategies for clinical translation. Dent Clin North Am. 2012:56:639-49.

21. Smith JG, Smith AJ, Shelton RM, Cooper PR. Recruitment of dental pulp cells by dentine and pulp extracellular matrix components. Exp Cell Res. 2012; 318:2397-406.

22. Torabinejad M, Turman M. Revitalization of tooth with necrotic pulp and open apex by using platelet-rich plasma: a case report. J Endod. 2011:37:265-8.

23. Reynolds K, Johnson JD, Cohenca N. Pulp revascularization of necrotic bilateral bicuspids using a modified novel technique to eliminate potential coronal discolouration: a case report. Int Endod J. 2009;42:84-92.

24. Hoshino E, Kurihara-Ando N, Sato I, Uematsu H, Sato M, Kota K, Iwaku M. Invitro antibacterial susceptibility of bacteria taken from infected root dentine to a mixture of ciprofloxacin, metronidazole and minocycline. Int Endod J. 1996:29:125-30.

25. Marconyak $L$, Jr., Kirkpatrick TC, Roberts HW, Roberts MD, Aparicio A, Himel VT, Sabey KA. A comparison of coronal tooth discoloration elicited by various endodontic reparative materials. J Endod. 2016;42:470-3.

26. Iwaya S, Ikawa M, Kubota M. Revascularization of an immature permanent tooth with periradicular abscess after luxation. Dent Traumatol. 2011;27:55-8.
27. Andreasen JO, Farik B, Munksgaard EC. Long-term calcium hydroxide as a root canal dressing may increase risk of root fracture. Dent Traumatol. 2002:18:134-7.

28. Sahebi S, Moazami F, Abbott P. The effects of short-term calcium hydroxide application on the strength of dentine. Dent Traumatol. 2010;26:43-6.

29. Andukuri A, Kushwaha M, Tambralli A, Anderson J, Dean D, Berry J, Sohn Y, Yoon Y, Brott B, Jun HW. A hybrid biomimetic nanomatrix composed of electrospun polycaprolactone and bioactive peptide amphiphiles for cardiovascular implants. Acta Biomater. 2011;7:225-33.

30. Ban K, Park HJ, Kim S, Andukuri A, Cho KW, Hwang JW, Cha HJ, Kim SY, Kim WS, Jun HW, Yoon YS. Cell therapy with embryonic stem cell-derived cardiomyocytes encapsulated in injectable nanomatrix gel enhances cell engraftment and promotes cardiac repair. ACS Nano. 2014;8:10815-25.

31. Ingber DE, Mow VC, Butler D, Niklason L, Huard J, Mao J, Yannas I, Kaplan D, Vunjak-Novakovic G. Tissue engineering and developmental biology: going biomimetic. Tissue Eng. 2006;12:3265-83.

32. Linde A. The extracellular matrix of the dental pulp and dentin. J Dent Res. 1985;64 Spec No:523-9.

33. Nanci A. Ten Cate's oral histology: development, structure, and function 7th ed. St. Louis: Mosby Elsevier; 2008.

34. Liu H, Gronthos S, Shi S. Dental pulp stem cells. Methods Enzymol. 2006;419: 99-113.

35. Tatullo M, Marrelli M, Shakesheff KM, White LJ. Dental pulp stem cells: function, isolation and applications in regenerative medicine. J Tissue Eng Regen Med. 2015;9:1205-16.

36. Hargreaves KM, Giesler T, Henry M, Wang Y. Regeneration potential of the young permanent tooth: what does the future hold? J Endod. 2008;34:S51-6.

37. Trope M. Regenerative potential of dental pulp. J Endod. 2008;34:S13-7.

38. Huang GT, Sonoyama W, Liu Y, Liu H, Wang S, Shi S. The hidden treasure in apical papilla: the potential role in pulp/dentin regeneration and bioroot engineering. J Endod. 2008;34:645-51.

39. AAE Clinical Considerations for a Regenerative Procedure [http://www. aae.org/uploadedfiles/clinical resources/regenerative endodontics/ considerationsregendo7-31-13.pdf]. Accessed 20 Mar 2016.

40. Ring KC, Murray PE, Namerow KN, Kuttler S, Garcia-Godoy F. The comparison of the effect of endodontic irrigation on cell adherence to root canal dentin. J Endod. 2008:34:1474-9.

41. Galler KM, D'Souza RN, Federlin M, Cavender AC, Hartgerink JD, Hecker S, Schmalz G. Dentin conditioning codetermines cell fate in regenerative endodontics. J Endod. 2011;37:1536-41.

42. Dabbagh B, Alvaro E, Vu DD, Rizkallah J, Schwartz S. Clinical complications in the revascularization of immature necrotic permanent teeth. Pediatr Dent. 2012;34:414-7.

43. Torabinejad M, Hong CU, Lee SJ, Monsef M, Pitt Ford TR. Investigation of mineral trioxide aggregate for root-end filling in dogs. J Endod. 1995:21:603-8.

44. Bogen G, Kim JS, Bakland LK. Direct pulp capping with mineral trioxide aggregate: an observational study. J Am Dent Assoc. 2008;139:305-15. quiz 305-315

45. Olsson $\mathrm{H}$, Petersson $\mathrm{K}$, Rohlin M. Formation of a hard tissue barrier after pulp cappings in humans. A systematic review. Int Endod J. 2006;39:429-42.

46. Sato $T$, Hoshino E, Uematsu $H$, Noda $T$. In vitro antimicrobial susceptibility to combinations of drugs on bacteria from carious and endodontic lesions of human deciduous teeth. Oral Microbiol Immunol. 1993:8:172-6.

47. Kim ST, Abbott PV, McGinley P. The effects of Ledermix paste on discolouration of immature teeth. Int Endod J. 2000;33:233-7.

48. Nosrat A, Li KL, Vir K, Hicks ML, Fouad AF. Is pulp regeneration necessary for root maturation? J Endod. 2013:39:1291-5.

49. Ruparel NB, Teixeira FB, Ferraz CC, Diogenes A. Direct effect of intracanal medicaments on survival of stem cells of the apical papilla. J Endod. 2012; 38:1372-5.

50. Frank AL. Therapy for the divergent pulpless tooth by continued apical formation. J Am Dent Assoc. 1966:72:87-93.

51. Cvek M. Prognosis of luxated non-vital maxillary incisors treated with calcium hydroxide and filled with gutta-percha. A retrospective clinical study. Endod Dent Traumatol. 1992;8:45-55

52. Chueh LH, Ho YC, Kuo TC, Lai WH, Chen YH, Chiang CP. Regenerative endodontic treatment for necrotic immature permanent teeth. J Endod. 2009:35:160-4.

53. Chueh LH, Huang GT. Immature teeth with periradicular periodontitis or abscess undergoing apexogenesis: a paradigm shift. J Endod. 2006 32:1205-13. 
54. Chen MY, Chen KL, Chen CA, Tayebaty F, Rosenberg PA, Lin LM. Responses of immature permanent teeth with infected necrotic pulp tissue and apical periodontitis/abscess to revascularization procedures. Int Endod J. 2012;45: 294-305.

55. Rosenberg B, Murray PE, Namerow K. The effect of calcium hydroxide root filling on dentin fracture strength. Dent Traumatol. 2007;23:26-9.

56. Yassen $\mathrm{GH}$, Vail MM, Chu TG, Platt JA. The effect of medicaments used in endodontic regeneration on root fracture and microhardness of radicular dentine. Int Endod J. 2013:46:688-95.

57. Webber RT. Apexogenesis versus apexification. Dent Clin North Am. 1984;28: 669-97

58. Myers WC, Fountain SB. Dental pulp regeneration aided by blood and blood substitutes after experimentally induced periapical infection. Oral Surg Oral Med Oral Pathol. 1974;37:441-50.

59. AAE. Regenerative endodontics. In: Endodontics colleagues for excellence. Chicago: American Association of Endodontists; 2013. p. 1-8.

60. Petrino JA, Boda KK, Shambarger S, Bowles WR, McClanahan SB. Challenges in regenerative endodontics: a case series. J Endod. 2010;36:536-41.

61. Nosrat A, Seifi A, Asgary S. Regenerative endodontic treatment (revascularization) for necrotic immature permanent molars: a review and report of two cases with a new biomaterial. J Endod. 2011;37:562-7.

62. Bose $R$, Nummikoski $P$, Hargreaves $K$. A retrospective evaluation of radiographic outcomes in immature teeth with necrotic root canal systems treated with regenerative endodontic procedures. J Endod. 2009;35:1343-9.

63. Saoud TM, Zaazou A, Nabil A, Moussa S, Aly HM, Okazaki K, Rosenberg PA, Lin LM. Histological observations of pulpal replacement tissue in immature dog teeth after revascularization of infected pulps. Dent Traumatol. 2015;31:243-9.

64. Yamauchi N, Nagaoka H, Yamauchi S, Teixeira FB, Miguez P, Yamauchi M. Immunohistological characterization of newly formed tissues after regenerative procedure in immature dog teeth. J Endod. 2011;37:1636-41.

65. Yamauchi N, Yamauchi S, Nagaoka H, Duggan D, Zhong S, Lee SM, Teixeira FB, Yamauchi M. Tissue engineering strategies for immature teeth with apical periodontitis.

J Endod. 2011;37:390-7.

66. Kobayashi M, Kagawa T, Takano R, Itagaki S, Hirano T, Iseki K. Effect of medium $\mathrm{pH}$ on the cytotoxicity of hydrophilic statins. J Pharm Pharm Sci. 2007;10:332-9.

67. Chuensombat S, Khemaleelakul S, Chattipakorn S, Srisuwan T. Cytotoxic effects and antibacterial efficacy of a 3-antibiotic combination: an in vitro study. J Endod. 2013;39:813-9.

68. Labban N, Yassen GH, Windsor LJ, Platt JA. The direct cytotoxic effects of medicaments used in endodontic regeneration on human dental pulp cells. Dent Traumatol. 2014:30:429-34.

69. Caplan Al. Mesenchymal stem cells. J Orthop Res. 1991;9:641-50.

70. Huang GT, Gronthos S, Shi S. Mesenchymal stem cells derived from dental tissues vs. those from other sources: their biology and role in regenerative medicine. J Dent Res. 2009:88:792-806.

71. Sedgley CM, Botero TM. Dental stem cells and their sources. Dent Clin North Am. 2012;56:549-61.

72. Hristov M, Erl W, Weber PC. Endothelial progenitor cells: mobilization, differentiation, and homing. Arterioscler Thromb Vasc Biol. 2003;23:1185-9.

73. Sedgley CM, Cherkas P, Chogle SMA, Geisler TM, Hargreaves KM, Paranjpe AK, Yamagishi VT-K. Regenerative endodontics. In: Endodontics: colleagues for excellence, vol. Spring. Chicago: American Association of Endodontists Foundation; 2013.

74. Iwaya SI, Ikawa M, Kubota M. Revascularization of an immature permanent tooth with apical periodontitis and sinus tract. Dent Traumatol. 2001;17:185-7.

75. Kling M, Cvek M, Mejare I. Rate and predictability of pulp revascularization in therapeutically reimplanted permanent incisors. Endod Dent Traumatol. 1986:2:83-9.

76. Huang GT, Garcia-Godoy F. Missing Concepts in De Novo Pulp Regeneration. J Dent Res. 2014;93:717-24.

77. Gronthos S, Brahim J, Li W, Fisher LW, Cherman N, Boyde A, DenBesten P, Robey PG, Shi S. Stem cell properties of human dental pulp stem cells. J Dent Res. 2002;81:531-5.

78. Sonoyama W, Liu Y, Fang D, Yamaza T, Seo BM, Zhang C, Liu H, Gronthos S, Wang $C Y$, Wang S, Shi S. Mesenchymal stem cell-mediated functional tooth regeneration in swine. PLoS One. 2006;1, e79.

79. Miura M, Gronthos S, Zhao M, Lu B, Fisher LW, Robey PG, Shi S. SHED: stem cells from human exfoliated deciduous teeth. Proc Natl Acad Sci U S A. 2003;100:5807-12.
80. Gronthos S, Mankani M, Brahim J, Robey PG, Shi S. Postnatal human dental pulp stem cells (DPSCs) in vitro and in vivo. Proc Natl Acad Sci U S A. 2000; 97:13625-30.

81. Nakashima M, Akamine A. The application of tissue engineering to regeneration of pulp and dentin in endodontics. J Endod. 2005;31:711-8.

82. Nosrat IV, Smith CA, Mullally P, Olson L, Nosrat CA. Dental pulp cells provide neurotrophic support for dopaminergic neurons and differentiate into neurons in vitro; implications for tissue engineering and repair in the nervous system. Eur J Neurosci. 2004;19:2388-98.

83. Ishizaka R, lohara K, Murakami M, Fukuta O, Nakashima M. Regeneration of dental pulp following pulpectomy by fractionated stem/progenitor cells from bone marrow and adipose tissue. Biomaterials. 2012;33:2109-18.

84. Huang GT, Al-Habib M, Gauthier P. Challenges of stem cell-based pulp and dentin regeneration: a clinical perspective. Endod Topics. 2013;28:51-60.

85. Iohara K, Zheng L, Wake H, Ito M, Nabekura J, Wakita H, Nakamura H, Into T, Matsushita K, Nakashima M. A novel stem cell source for vasculogenesis in ischemia: subfraction of side population cells from dental pulp. Stem Cells. 2008;26:2408-18.

86. Nakashima M, lohara K, Sugiyama M. Human dental pulp stem cells with highly angiogenic and neurogenic potential for possible use in pulp regeneration. Cytokine Growth Factor Rev. 2009;20:435-40.

87. Gruetter CA, Barry BK, McNamara DB, Gruetter DY, Kadowitz PJ, Ignarro L. Relaxation of bovine coronary artery and activation of coronary arterial guanylate cyclase by nitric oxide, nitroprusside and a carcinogenic nitrosoamine. J Cyclic Nucleotide Res. 1979;5:211-24.

88. Kimura $H$, Esumi $H$. Reciprocal regulation between nitric oxide and vascular endothelial growth factor in angiogenesis. Acta Biochim Pol. 2003:50:49-59.

89. Sun B, Slomberg DL, Chudasama SL, Lu Y, Schoenfisch MH. Nitric oxide-releasing dendrimers as antibacterial agents. Biomacromolecules. 2012;13:3343-54.

90. Backlund CJ, Worley BV, Schoenfisch MH. Anti-biofilm action of nitric oxide-releasing alkyl-modified poly(amidoamine) dendrimers against Streptococcus mutans. Acta Biomater. 2016;29:198-205.

91. Nakashima M, Nagasawa H, Yamada Y, Reddi AH. Regulatory role of transforming growth factor-beta, bone morphogenetic protein-2, and protein-4 on gene expression of extracellular matrix proteins and differentiation of dental pulp cells. Dev Biol. 1994;162:18-28.

92. Nakashima M, Reddi AH. The application of bone morphogenetic proteins to dental tissue engineering. Nat Biotechnol. 2003;21:1025-32.

93. Nakashima M. Induction of dentin formation on canine amputated pulp by recombinant human bone morphogenetic proteins (BMP)-2 and -4 . J Dent Res. 1994;73:1515-22.

94. Liu J, Jin T, Ritchie HH, Smith AJ, Clarkson BH. In vitro differentiation and mineralization of human dental pulp cells induced by dentin extract. In Vitro Cell Dev Biol Anim. 2005:41:232-8.

95. Liu J, Jin TC, Chang S, Czajka-Jakubowska A, Clarkson BH. Adhesion and growth of dental pulp stem cells on enamel-like fluorapatite surfaces. J Biomed Mater Res A. 2011;96:528-34.

96. Wang $X$, Jin T, Chang S, Zhang Z, Czajka-Jakubowska A, Nor JE, Clarkson BH, Ni L, Liu J. In vitro differentiation and mineralization of dental pulp stem cells on enamel-like fluorapatite surfaces. Tissue Eng Part C Methods. 2012; 18:821-30.

97. Slavkin HC, Bartold PM. Challenges and potential in tissue engineering. Periodontol 2000. 2006:41:9-15.

98. Anitua E, Sanchez M, Nurden AT, Nurden P, Orive G, Andia I. New insights into and novel applications for platelet-rich fibrin therapies. Trends Biotechnol. 2006:24:227-34

99. Ogino Y, Ayukawa Y, Kukita T, Koyano K. The contribution of platelet-derived growth factor, transforming growth factor-beta1, and insulin-like growth factor-I in platelet-rich plasma to the proliferation of osteoblast-like cells. Oral Surg Oral Med Oral Pathol Oral Radiol Endod. 2006;101:724-9.

100. Lee UL, Jeon SH, Park JY, Choung PH. Effect of platelet-rich plasma on dental stem cells derived from human impacted third molars. Regen Med. 2011;6:67-79.

101. Del Fabbro M, Lolato A, Bucchi C, Taschieri S, Weinstein RL. Autologous platelet concentrates for pulp and dentin regeneration: a literature review of animal studies. J Endod. 2016;42:250-7.

102. Iohara K, Imabayashi K, Ishizaka R, Watanabe A, Nabekura J, Ito M, Matsushita K, Nakamura H, Nakashima M. Complete pulp regeneration after pulpectomy by transplantation of CD105+ stem cells with stromal cellderived factor-1. Tissue Eng Part A. 2011;17:1911-20.

103. Lapidot T, Dar A, Kollet O. How do stem cells find their way home? Blood. 2005;106:1901-10 
104. Kavanagh DP, Kalia N. Hematopoietic stem cell homing to injured tissues. Stem Cell Rev. 2011;7:672-82

105. Hopman RK, DiPersio JF. Advances in stem cell mobilization. Blood Rev. 2014:28:31-40.

106. Zhou J, Shi S, Shi Y, Xie H, Chen L, He Y, Guo W, Wen L, Jin Y. Role of bone marrow-derived progenitor cells in the maintenance and regeneration of dental mesenchymal tissues. J Cell Physiol. 2011;226:2081-90.

107. Huang GT, Yamaza T, Shea LD, Djouad F, Kuhn NZ, Tuan RS, Shi S. Stem/ progenitor cell-mediated de novo regeneration of dental pulp with newly deposited continuous layer of dentin in an in vivo model. Tissue Eng Part A. 2010;16:605-15.

108. Hersel U, Dahmen C, Kessler H. RGD modified polymers: biomaterials for stimulated cell adhesion and beyond. Biomaterials. 2003;24:4385-415.

109. Weber LM, Hayda KN, Haskins K, Anseth KS. The effects of cell-matrix interactions on encapsulated beta-cell function within hydrogels functionalized with matrixderived adhesive peptides. Biomaterials. 2007;28:3004-11.

110. Park KH, Na K, Jung SY, Kim SW, Park KH, Cha KY, Chung HM. Insulinoma cell line (MIN6) adhesion and spreading mediated by Arg-Gly-Asp (RGD) sequence conjugated in thermo-reversible gel. J Biosci Bioeng. 2005;99:598-602.

111. Baroli B. Photopolymerization of biomaterials: issues and potentialities in drug delivery, tissue engineering, and cell encapsulation applications. J Chem Technol Biotechnol. 2006;81:491-9.

112. King A, Sandler S, Andersson A. The effect of host factors and capsule composition on the cellular overgrowth on implanted alginate capsules. J Biomed Mater Res. 2001;57:374-83.

113. Anderson J, Patterson J, Vines J, Javed A, Gilbert S, Jun H. Biphasic peptide amphiphile nanomatrix embedded with hydroxyapatite nanoparticles for stimulated osteoinductive response. ACS Nano. 2011;5:9463-79.

114. Jun H-W, Yuwono V, Paramonov SE, Hartgerink JD. Enzyme-mediated degradation of peptide-amphiphile nanofiber networks. Adv Mater. 2005;17:2612-7.

115. Hartgerink JD, Beniash E, Stupp SI. Self-assembly and mineralization of peptide-amphiphile nanofibers. Science. 2001;294:1684-8.

116. Anderson JM, Kushwaha M, Tambralli A, Bellis SL, Camata RP, Jun HW. Osteogenic differentiation of human mesenchymal stem cells directed by extracellular matrix-mimicking ligands in a biomimetic self-assembled peptide amphiphile nanomatrix. Biomacromolecules. 2009;10:2935-44.

117. Anderson JM, Andukuri A, Lim DJ, Jun HW. Modulating the gelation properties of self-assembling peptide amphiphiles. ACS Nano. 2009;3:3447-54.

118. Kushwaha M, Anderson JM, Bosworth CA, Andukuri A, Minor WP, Lancaster JR, Jr., Anderson PG, Brott BC, Jun HW. A nitric oxide releasing, self assembled peptide amphiphile matrix that mimics native endothelium for coating implantable cardiovascular devices. Biomaterials. 2010;31:1502-8.

119. Kaushik SN, Scoffield J, Andukuri A, Alexander GC, Walker T, Kim S, Choi SC, Brott BC, Eleazer PD, Lee JY, et al. Evaluation of Ciprofloxacin and Metronidazole Encapsulated Biomimetic Nanomatrix Gel on Enterococcus faecalis and Treponema denticola. Biomater Res. 2015;19:9.

120. Torabinejad M, Corr R, Buhrley M, Wright K, Shabahang S. An animal model to study regenerative endodontics. J Endod. 2011;37:197-202.

121. Torabinejad M, Bakland LK. An animal model for the study of immunopathogenesis of periapical lesions. J Endod. 1978;4:273-7.

122. Zhao C, Hosoya A, Kurita H, Hu T, Hiraga T, Ninomiya T, Yoshiba K, Yoshiba $\mathrm{N}$, Takahashi M, Kurashina K, et al. Immunohistochemical study of hard tissue formation in the rat pulp cavity after tooth replantation. Arch Oral Biol. 2007:52:945-53.

123. He T, Kiliaridis S. Craniofacial growth in the ferret (Mustela putorius furo)-a cephalometric study. Arch Oral Biol. 2004;49:837-48.

124. Wilson G. Timing of apical closure of the maxillary canine and mandibular first molar teeth of cats. J Vet Dent. 1999;16:19-21.

125. Khademi AA, Dianat O, Mahjour F, Razavi SM, Younessian F. Outcomes of revascularization treatment in immature dog's teeth. Dent Traumatol. 2014; 30:374-9.

126. Yildirim S, Can A, Arican M, Embree MC, Mao JJ. Characterization of dental pulp defect and repair in a canine model. Am J Dent. 2011;24:331-5.

127. Wilson G. Implications of the time of apical closure in relation to tooth fracture in dogs. Aus Vet Practit. 1996;26:65-71.

\section{Submit your next manuscript to BioMed Central and we will help you at every step:}

- We accept pre-submission inquiries

- Our selector tool helps you to find the most relevant journal

- We provide round the clock customer support

- Convenient online submission

- Thorough peer review

- Inclusion in PubMed and all major indexing services

- Maximum visibility for your research

Submit your manuscript at www.biomedcentral.com/submit
Biomed Central 